\title{
COMPARISON OF FOUR TECHNIQUES TO ESTIMATE FORAGE INTAKE BY RAMS GRAZING ON A Panicum coloratum L. PASTURE
}

\author{
Carlos M. Ferri ${ }^{1^{*}}$, Néstor P. Stritzler ${ }^{2}$, Miguel A. Brizuela ${ }^{3}$, and Horacio J. Pagella ${ }^{1}$
}

\begin{abstract}
A B S T R A C T
The estimation of daily feed intake is important in the determination of animal production The objective of this experiment was to compare measurements of animal forage intake obtained by the use of four techniques: preand post-grazing difference in standing forage mass, total daily feces collection in combination with in vitro diet digestibility, total daily feces collection in combination with diet digestibility estimated by the fecal nitrogen index and the $n$-alkane technique. The experiment was carried out on a stockpiled Panicum coloratum L. pasture during two growing seasons. The treatments for the first season comprised standing forage mass accumulated after mid-October, mid-January and mid-February mechanical harvest to 8-cm stubble. In the second season, the treatments came from forage mass accumulated after mid-December, early January and February cuttings. Treatments were assigned at random to 0.5 ha plots in two replicates. The most closely correlated estimations of intake $(r=0.83$; $\mathrm{P}<0.01)$ were those obtained through total collection of feces and diet digestibility and the least with either the in vitro technique or the fecal $\mathrm{N}$ index. The apparent overestimation of intake by the $n$-alkane technique might be a consequence of the bias produced by forage sampling. In general terms, the techniques used to estimate intake were responsive to treatment effect.
\end{abstract}

Key words: $\mathrm{C}_{4}$ grass, fecal nitrogen, forage intake, $n$-alkanes.

\section{INTRODUCTION}

Dietary intake is the major factor in the determination of animal production (Lippke, 2002). Therefore, the estimation of the daily quantity of dry material consumed by an animal is essential to make nutritional inferences about the feed and the subsequent animal response. The quantification of forage intake under grazing conditions is complicated and the techniques used have in general some limitations in terms of introducing errors (Mayes and Dove, 2000). The technique selection will depend on availability of resources, precision, accuracy and type of estimation required (individual or group, shortor long-term evaluations, for example).

Forage daily intake can be estimated through the difference between pre- and post-grazing measurements of biomass (Coates and Penning, 2000). This technique provides reliable estimates of intake when grazing periods are short and a high proportion of forage on offer is consumed (Macoon et al., 2003). The main disadvantages are under-estimation of forage intake because of pasture growth and variability between determinations.

The conventional procedure used to estimate individual daily intake is based on the relationship between daily excretion of feces $(\mathrm{H})$ and diet digestibility (generally in terms of organic matter, OMD). The main factor that limits the accuracy of OMD determinations is the collection of representative samples of the animals' diet (Lippke, 2002).

The use of the technique in vitro to estimate OMD has the disadvantage of assuming a single value for diet

\footnotetext{
${ }^{1}$ Universidad Nacional de La Pampa, Facultad de Agronomía, CC 300, L-6300, Santa Rosa, La Pampa, Argentina. E-mail: ferri@agro.unlpam.edu.ar *Corresponding author.

${ }^{2}$ Instituto Nacional de Tecnología Agropecuaria, Estación Experimental Anguil “Ing. Agr. Guillermo Covas”, CC 11, L-6326, Anguil, La Pampa, Argentina.

${ }^{3}$ Universidad Nacional de Mar del Plata, Facultad de Ciencias Agrarias, CIC Bs. As., CC 276, B-7620, Balcarce, Buenos Aires, Argentina.

Received: 9 April $2007 . \quad$ Accepted: 15 June 2007.
} 
digestibility without considering the variation among animals, feed intake level and physiological state of the animals (Coates and Penning, 2000). On the other hand, the fecal index technique does not require diet sampling (Ferri et al., 2003) and only involves routine chemical determinations. Nevertheless, it presents a series of problems related to the extrapolation of equations obtained in stall-feeding trials to the grazing condition (Rymer, 2000). According to Coates and Penning (2000), the reliability of such type of extrapolations is affected by factors related to the animal (species, physiological state, parasitic load, feed intake level) and the plant (species, morphological fraction, growing season, nitrogen fertilization).

The $n$-alkanes present naturally in plant cuticle wax, together with the oral administration of synthetic $n$ alkanes, can be used as markers to estimate individual forage intake (Lippke, 2002). Estimation of intake through the use of adjacent $n$-alkanes pairs (one natural, with an odd number of carbon atoms, and the other dosed, with an even number of carbon atoms) with similar recovery level in feces allows for canceling out the error introduced by incomplete fecal recovery. The $n$-alkanes technique has the advantage that it does not require previous estimations of daily excretion of faeces nor diet digestibility, but does require representative samples of the diet. Besides, it is not affected by factors inherent to the feed and the animal that could modify digestibility (Mayes and Dove, 2000).

This work evaluated four techniques for estimating forage intake of rams grazing a Panicum coloratum cv. Verde pasture upon different periods of forage accumulation. The objective was to compare estimates of forage intake obtained by four techniques and identify the most suitable ones for determining forage intake by grazing sheep. The techniques assayed were: forage mass difference between pre- and postgrazing cuttings, total feces collection combined with diet digestibility in vitro adjusted by the equation of Meijs et al. (1982), total feces collection combined with diet digestibility using the fecal $\mathrm{N}$ index, and the $n$-alkanes method.

\section{MATERIALS AND METHODS}

A pasture of Panicum coloratum cv. Verde, established in spring 1994, at the Agronomy Faculty Experimental Farm, Universidad Nacional de La Pampa, La Pampa, Argentina ( $36^{\circ} 46^{\prime} \mathrm{S}, 64^{\circ} 16^{\prime} \mathrm{W}, 210$ m.a.s.l.), was used during two growing seasons, 1996-1997 and 1997-1998.

Different periods of forage accumulation at pasture gave rise to the applied treatments (Table 1). During the first growing season these were set up by allowing forage accumulation until pasture growth ceased owing to low temperatures. The forage was then mechanically harvested to $8 \mathrm{~cm}$ of stubble in mid-October $\left(\mathrm{T}_{1} 270\right)$, mid-January $\left(T_{1} 175\right)$ and mid-February $\left(T_{1} 145\right)$. The treatments in the second season were generated after harvest in mid-December $\left(\mathrm{T}_{2} 215\right)$, beginning of January $\left(T_{2} 195\right)$ and beginning of February $\left(T_{2} 165\right)$. The subindex of each treatment indicates the growing season, and the following number indicates the duration in days of each accumulation period counted from the cutting day until the first day of the grazing test. The treatments were randomly assigned in 0.5 -ha plots, with two replicates. Six forage accumulation period-lengths were generated as a function of growing season duration for $P$. coloratum in the local region. For each treatment and replicate 22 sub-plots (daily strips) were used, of which 14 corresponded to the adaptation period and eight to the measurement period. The grazing periods began on 12 June 1997 and 16 July 1998.

Table 1. Details of the treatments applied to a Panicum coloratum cv. Verde pasture, during two growing seasons (1996-1997 and 1997-1998).

\begin{tabular}{ccccc}
\hline $\begin{array}{c}\text { Growing } \\
\text { season }\end{array}$ & Treatment $^{\mathbf{1}}$ & $\begin{array}{c}\text { Treatment } \\
\text { initiation date }\end{array}$ & $\begin{array}{c}\text { Grazing initiation } \\
\text { date }\end{array}$ & $\begin{array}{c}\text { Forage accumulation } \\
\text { period (days) }\end{array}$ \\
\hline $1996-1997$ & $\mathrm{~T}_{1} 270$ & $17 / 10 / 1996$ & $12 / 07 / 1997$ & 268 \\
& $\mathrm{~T}_{1} 175$ & $16 / 01 / 1997$ & & 177 \\
& $\mathrm{~T}_{1} 145$ & $14 / 02 / 1997$ & & 148 \\
$1997-1998$ & $\mathrm{~T}_{2} 215$ & $11 / 12 / 1997$ & $16 / 07 / 1998$ & 216 \\
& $\mathrm{~T}_{2} 195$ & $02 / 01 / 1998$ & & 195 \\
& $\mathrm{~T}_{2} 165$ & $02 / 02 / 1998$ & & 164 \\
\hline
\end{tabular}

${ }^{1}$ The sub-index indicates the growing season and the following number indicates the duration in days of each forage accumulation period. 
Grazing was conducted in daily strips with five Pampinta breed rams, with an initial live weight (LW) of $49.6 \pm 5.1 \mathrm{~kg}$ in 1997, and $45.4 \pm 5.2 \mathrm{~kg}$ in 1998. Three of the animals were harnessed with bags for collecting faeces. The animals were weighed every 7 days and mean LW was used to calculate individual intake per unit of metabolic live weight $\left(\mathrm{LW}^{0,75}\right)$. The allowance of forage was established at $40 \mathrm{~g}$ of $\mathrm{DM} \mathrm{kg}^{-1} \mathrm{LW}$ day ${ }^{-1}$. This allowance would allow for a harvest efficiency of approximately $50 \%$, according to measurements carried out in the same pasture, following forage accumulation since the end of February (Ferri et al., 2001). The necessary area to provide the established allowance for each sub-plot (range: 29 to $60 \mathrm{~m}^{2}$ in 1997 and 37 to $53 \mathrm{~m}^{2}$ in 1998) was determined the day before starting its grazing (preP), by measuring the availability of forage based on three cuttings $\left(1.0 \mathrm{~m}^{2}\right)$ of biomass at ground level. The residual forage (post-grazing: pos-P) was determined by three measurements, each nearby the pre-P cutting (matched samples).

\section{Chemical-biological analysis of forage}

Following a sequence of oven-drying $\left(55^{\circ} \mathrm{C}, 72 \mathrm{~h}\right)$ and grinding in a Wiley mill ( $1 \mathrm{~mm}$ screen), the samples from each set of pre-P or pos-P cuttings were pooled together, taking fixed quantities based on weight to obtain three samples per treatment and replicate. The dry matter (DM) was determined at $105^{\circ} \mathrm{C}$ for $48 \mathrm{~h}$, and the ash concentration was measured gravimetrically following burning of the sample in a muffle furnace at $550{ }^{\circ} \mathrm{C}$ for $12 \mathrm{~h}$. The concentration of crude protein $(\mathrm{CP}$; $\mathrm{N} x$ 6.25) was determined by the Kjeldahl semi-micro procedure (Digestion Unit 2040 and Distilling Unit 1026, Tecator, Högänas, Sweden) and the concentrations of fiber in neutral (NDF) and acid (ADF) detergents and lignin in acid detergent (ADL) using the procedure described by Van Soest and Robertson (1985). In vitro organic matter digestibility (IVOMD) was determined in accordance to Alexander and McGowan (1966). The samples were incubated at $39^{\circ} \mathrm{C}$ for $72 \mathrm{~h}$ in a solution of artificial saliva and ruminal liquor, followed by an additional period of $24 \mathrm{~h}$ in a solution of hydrochloric acid and pepsin. The innoculum for the procedure was obtained from a steer prepared with rumen fistula and fed ad libitum with alfalfa hay (Medicago sativa $\mathrm{L}$.). Estimations of IVOMD were corrected using the in vitro:in vivo digestibility relationship from a control forage sample ( $P$. coloratum forage, with an in vivo digestibility of $\left.509 \mathrm{~g} \mathrm{~kg}^{-1} \mathrm{DM}\right)$.

\section{Estimation of dietary intake}

Organic matter intake (OMI) was estimated using both direct and indirect methods. The direct approach was based on forage mass measurement at pasture. Indirect determinations of intake were carried out by total collection of feces combined with in vitro digestibility of the diet adjusted using the equation of Meijs et al. (1982), total collection of feces combined with diet digestibility estimated based on the fecal $\mathrm{N}$ index, and the use of $n$-alkanes (Mayes and Dove, 2000) as internal and external fecal markers.

\section{Direct or herbage cutting method}

OMI was estimated directly by the difference between forage measured in pre- and post-grazing herbage cuttings (Coates and Penning, 2000). Grown forage mass was not considered, given that the period between cuttings was 1 day and that pasture growth is generally null in the winter.

\section{Indirect methods}

The individual OMI of the animals, using data of total collection of feces, was calculated using the following equation:

$\mathrm{OMI}=\mathrm{H} /[1-\mathrm{OMD} / 1000)]$

where $\mathrm{H}$ is the daily excretion of OM in feces $\left(\mathrm{g} \mathrm{day}^{-1}\right)$ and OMD $\left(\mathrm{g} \mathrm{kg}^{-1} \mathrm{MS}\right)$ the apparent OM digestibility of the diet. The feces excreted per animal were collected and weighed twice a day (08:00 and 17:30 h). Samples of $250 \mathrm{~g}$ were then taken for drying and grinding, in the same way as described for forage sampling, to subsequently determine DM, ash, $\mathrm{N}$ and $n$-alkanes concentrations. The samples corresponding to each animal were composed, for the measurement period, on the basis of the total quantity of DM excreted daily. OMD was estimated by either the in vitro technique $\left(\mathrm{OMD}_{\text {in vitro }}\right)$ or the fecal $\mathrm{N}$ index technique $\left(\mathrm{OMD}_{\mathrm{N} \text { fecal }}\right)$.

\section{Adjusted in vitro digestibility}

The digestibility of the diet was estimated in accordance to the equation of Meijs et al. (1982) as follows:

$\mathrm{OMD}_{\text {in viro }}=[($ Fpre x IVOMD)-(Fpos x IVOMD $] /($ Fpre-Fpos $)$

where Fpre and Fpost represent pre- and post-grazing forage biomass, respectively, and IVOMDpre and IVOMDpos are in vitro OM digestibility of in pre- and post-grazing, respectively. 


\section{Fecal $\mathbf{N}$ index}

The ratio of $\mathrm{N}$ concentrations in fecal OM and OMD, relies on the reduction of fecal $\mathrm{OM}$ excretion and the increase in $\mathrm{N}$ fecal concentration when diet $\mathrm{OM}$ digestibility increases (Lukas et al., 2005). As a consequence, based on the value of NTF $\left(\mathrm{g} \mathrm{kg}^{-1} \mathrm{OMI}\right)$ and the concentration of $\mathrm{N}$ in fecal OM (cNF; $\mathrm{g} \mathrm{kg}^{-1}$ $\mathrm{OM}$ ), the quantity of forage $\mathrm{OM}$ that would determine $1000 \mathrm{~g}$ of fecal OM would be $1000 \mathrm{x} \mathrm{cNF} / \mathrm{NTF}$, and digestibility would be calculated as follow:

$\mathrm{OMD}_{\mathrm{N} \text { fecal }}=\{[1000 x \mathrm{cNF} / \mathrm{NTF})-1000] / 1000 x \mathrm{cNF}$ $/ \mathrm{NTF}\} \times 1000=1000 \times(1-\mathrm{NTF} / \mathrm{cNF})$

where the value of NTF (7.15 $\left.\mathrm{g} \mathrm{kg}^{-1} \mathrm{OMI}\right)$ was taken from the work of Ferri et al. (2003).

\section{$N$-alkanes}

OMI was estimated in accordance to the equation proposed by Mayes et al. (1995):

$$
\mathrm{OMI}=(\mathrm{Dj} \times \mathrm{Hi} / \mathrm{Hj}) /[\mathrm{Fi}-(\mathrm{Fj}-\times \mathrm{Hi} / \mathrm{Hj})]
$$

where, $\mathrm{H}_{\mathrm{i}}$ and $\mathrm{F}_{\mathrm{i}}$ are the concentrations $\left(\mathrm{mg} \mathrm{kg}^{-1} \mathrm{OM}\right)$ of $n$-alkanes with an odd number of carbon atoms in feces and forage, respectively; $\mathrm{H}_{\mathrm{j}}$ and $\mathrm{F}_{\mathrm{j}}$ are the concentrations ( $\mathrm{mg} \mathrm{kg}^{-1} \mathrm{OM}$ ) of $n$-alkanes with an even number of carbon atoms in feces and forage ( $\left.\mathrm{mg} \mathrm{kg}^{-1} \mathrm{OM}\right)$, respectively, and $\mathrm{D}_{\mathrm{j}}$ is the dose of $n$-alkane $\left(n-\mathrm{C}_{32} ; \mathrm{mg} \mathrm{d}^{-1}\right)$. The estimations of OMI were obtained based on the combination of the $n-\mathrm{C}_{31}: n-\mathrm{C}_{32}$ and $n-\mathrm{C}_{33}: n-\mathrm{C}_{32}$ pairs.

Three animals were used per treatment and replicate, and dosed twice a day $(08: 00$ and 17:30 h) a pellet containing $n$-dotriacontane $\left(n-\mathrm{C}_{32} ; 106 \mathrm{mg}\right)$. After the pellets were administered, the animals were observed for $10 \mathrm{~min}$ to verify effective swallowing. Pellets were prepared at the Macaulay Land Use Research Institute (MLURI), Aberdeen, United Kingdom. The procedure to determine the concentration of $n$-alkanes in samples of forage, feces and pellets, involved the extraction and analysis (identification and quantification) of the extract using gas chromatography. The extraction of the $n$-alkanes was done following the procedure described by Mayes et al. (1986) and its analysis, by gas chromatography, was carried out at the MLURI. The characterization of the $n$-alkanes in the forage was described by Ferri et al. (2007).

\section{Statistical analysis}

The effects of growing season and treatments on chemical-biological attributes of forage were evaluated using variance analysis based on the model $\mathrm{Y}_{\mathrm{ijk}}=$ $\mu+\alpha_{i}+\alpha_{i}\left(\beta_{j}\right)+\tau_{k}\left(\alpha_{i}\right)+\varepsilon_{i j k}$, where $\mu$ is the general mean, $\alpha, \beta$ and $\tau$ are the effects of season, repetition and treatment and $\varepsilon_{\mathrm{ijk}}$ is the random error term of the sub-plot. The comparisons between intake estimation techniques were made based on the model, $\mathrm{Y}_{\mathrm{ijk} \mathrm{l}}=\mu+$ $\alpha_{\mathrm{i}}+\alpha_{\mathrm{i}}\left(\beta_{\mathrm{j}}\right)+\tau_{\mathrm{k}}\left(\alpha_{\mathrm{i}}\right)+\delta_{\mathrm{l}}+\alpha_{\mathrm{i}} \mathrm{x} \delta_{1}+\tau_{\mathrm{k}} \mathrm{x} \delta_{\mathrm{l}}\left(\alpha_{\mathrm{i}}\right)+\varepsilon_{\mathrm{ijk}}$, where $\mu$ is the general mean, $\alpha, \beta, \tau$ and $\delta$ are the effects of season, repetition, treatment and techniques, and $\varepsilon_{\mathrm{ijk} 1}$ is the random error term of the sub-plot. The effect of season was tested with $\alpha_{i}\left(\beta_{\mathrm{j}}\right)$. Comparisons of means were made using the Tukey test $(\alpha=0.05)$.

\section{RESULTS AND DISCUSSION}

\section{Chemical-biological characterization of the forage}

The shortening of the forage accumulation periods in both growth seasons determined significant increases $(\mathrm{P}<0.05)$ in $\mathrm{CP}$ concentration and a slight decrease $(\mathrm{P}<0.05)$ in that of NDF, while ADF concentration did not present any variations $(\mathrm{P}>0.05)$ (Table 2). IVOMD was greater $(\mathrm{P}<0.05)$ for the intermediate period of accumulation $\left(\mathrm{T}_{1} 175\right)$ during the 1996-1997 growing season, while in the following season (19971998) no differences were detected $(P>0.05)$ among accumulation periods.

\section{Comparison of estimates of organic matter intake using different techniques}

The treatment mean OMI estimated by each technique interacted $(\mathrm{P}=0.0015)$ with the growing season (Table 3). The OMI mean for the 1996-1997 growing season obtained through the cutting technique was higher $(\mathrm{P}<0.05)$ when compared to that of total collection of feces combined with $\mathrm{OMD}_{\mathrm{N} \text { fecal }}$, and similar $(\mathrm{P}>0.05)$, in both seasons, to that of the total collection of feces combined with $\mathrm{OMD}_{\text {in vitro. The }}$ means obtained through the total collection of feces combined with OMD using the technique in vitro or the fecal $\mathrm{N}$ index, were similar $(\mathrm{P}>0.05)$ in both seasons. With the $n$-alkanes technique using the $n-\mathrm{C}_{31}: n-\mathrm{C}_{32}$ and $n-\mathrm{C}_{33}: n-\mathrm{C}_{32}$ pairs, the means did not differ $(\mathrm{P}>$ 0.05) during the 1996-1997 growing season. During the following season (1997-1998) the mean for the $n-\mathrm{C}_{33}: n-\mathrm{C}_{32}$ pair was lower $(\mathrm{P}<0.05)$. In both seasons the mean OMI was higher $(\mathrm{P}<0.05)$ with the $n$-alkane technique than with the other techniques evaluated. On the other hand, the interaction technique $\mathrm{x}$ treatment 
Table 2. Chemical composition and in vitro organic matter (OM) digestibility of Panicum coloratum cv. Verde, with six initiation dates of forage accumulation, during two growing seasons (1996-1997 and 1997-1998).

\begin{tabular}{|c|c|c|c|c|c|c|c|}
\hline \multirow[t]{2}{*}{ Variables } & \multicolumn{6}{|c|}{ Treatments ${ }^{1}$} & \multirow[t]{2}{*}{ SE } \\
\hline & $T_{1} 270$ & $T_{1} 175$ & $T_{1} 145$ & $T_{2} 215$ & $T_{2} 195$ & $T_{2} 165$ & \\
\hline \multirow{3}{*}{ Ash } & & & $-\mathrm{gk}$ & $\overline{M S-}$ & & & \multirow{3}{*}{7} \\
\hline & $73 b$ & $93 \mathrm{ab}$ & $120 \mathrm{a}$ & $73 b$ & $81 \mathrm{ab}$ & $88 \mathrm{ab}$ & \\
\hline & & & $\mathrm{g} \mathrm{k}$ & $\mathrm{OM}$ & & & \\
\hline Crude protein & $26 \mathrm{~cd}$ & $29 \mathrm{c}$ & $34 \mathrm{~b}$ & $24 d$ & $27 \mathrm{~cd}$ & $37 a$ & 1 \\
\hline Neutral detergent fiber & $815 \mathrm{ab}$ & $806 a b$ & $792 b$ & $821 \mathrm{a}$ & $815 \mathrm{ab}$ & $801 \mathrm{ab}$ & 5 \\
\hline Acid detergent fiber & $500 \mathrm{a}$ & $492 a$ & $502 a$ & $482 \mathrm{a}$ & $482 \mathrm{a}$ & $485 \mathrm{a}$ & 8 \\
\hline Lignin acid detergent & $75 \mathrm{a}$ & $73 a$ & $73 a$ & $62 \mathrm{ab}$ & $56 \mathrm{~b}$ & $63 \mathrm{ab}$ & 2 \\
\hline In vitro digestibility & $385 \mathrm{~b}$ & $401 \mathrm{a}$ & $361 d$ & $381 b c$ & $381 \mathrm{bc}$ & $367 \mathrm{~cd}$ & 3 \\
\hline
\end{tabular}

Means with different letters in each row differ among themselves according to the Tukey test $(\mathrm{P}<0.05)$.

SE: mean standard error.

${ }^{1}$ Accumulation of forage produced throughout the 1996-1997 growing season $\left(\mathrm{T}_{1} 270\right)$, and after cuttings during that season carried out in mid-January $\left(T_{1} 175\right)$ and February $\left(T_{1} 145\right)$, and after cuttings made in mid-December $\left(T_{2} 215\right)$, early January $\left(\mathrm{T}_{2} 195\right)$ and February $\left(\mathrm{T}_{2} 165\right)$ during the 1997-1998 growing season.

Table 3. Organic matter intake by rams grazing on Panicum coloratum cv. Verde as estimated by preand post-grazing (pre- $\mathrm{P}$ - pos- $\mathrm{P}$ ) difference in standing forage mass, the total daily feces collection in combination with organic matter diet digestibility, assessed by the in vitro technique $\left(\mathrm{OMD}_{\text {in viro }}\right)$ or the fecal $\mathrm{N}$ index $\left(O M D_{\mathrm{N} \text { fecal }}\right)$, and the n-alkane technique using $n-\mathrm{C}_{31}: n-\mathrm{C}_{32}$ or $n-\mathrm{C}_{33}: n-\mathrm{C}_{32}$ pairs.

\begin{tabular}{|c|c|c|c|c|c|c|}
\hline \multirow{2}{*}{ Treatment } & \multirow{2}{*}{$\begin{array}{l}\text { Pre-P-pos- } \\
\text { P forage }\end{array}$} & \multicolumn{2}{|c|}{ Total collection of feces } & \multicolumn{2}{|c|}{$N$-alkanes } & \multirow{2}{*}{ Mean $^{1}$} \\
\hline & & $\mathbf{O M D}_{\text {in vitro }}$ & $\mathbf{O M D}_{N \text { fecal }}$ & $n-C_{31}: n-C_{32}$ & $n-C_{33}: n-C_{32}$ & \\
\hline & & & $\mathrm{g} \mathrm{kg} \mathrm{LW}^{-0,7}$ & & & \\
\hline $\mathrm{T}_{1} 270$ & 46.6 & 40.9 & 36.8 & 56.8 & 58.0 & $47.8 \mathrm{~cd}$ \\
\hline $\mathrm{T}_{1} 175$ & 46.6 & 42.0 & 37.7 & 57.3 & 57.8 & $48.3 \mathrm{bcd}$ \\
\hline $\mathrm{T}_{1}^{1} 145$ & 55.5 & 47.8 & 44.5 & 58.0 & 60.8 & $53.3 \mathrm{ab}$ \\
\hline Mean ${ }^{2}$ & $49.6 \mathrm{~b}$ & $43.7 \mathrm{bc}$ & $39.3 \mathrm{c}$ & $56.8 \mathrm{a}$ & $58.4 \mathrm{a}$ & 49.6 \\
\hline $\mathrm{T}_{2} 215$ & 34.9 & 37.6 & 35.8 & 55.8 & 51.3 & $43.1 \mathrm{~d}$ \\
\hline $\mathrm{T}_{2} 195$ & 37.2 & 41.6 & 40.5 & 69.2 & 61.5 & $50.0 \mathrm{abc}$ \\
\hline $\mathrm{T}_{2} 165$ & 46.5 & 50.7 & 42.8 & 68.9 & 57.3 & $53.2 \mathrm{a}$ \\
\hline Mean $^{3}$ & $39.5 \mathrm{c}$ & $42.9 \mathrm{c}$ & $40.5 \mathrm{c}$ & $64.1 \mathrm{a}$ & $56.4 \mathrm{~b}$ & 48.7 \\
\hline
\end{tabular}

${ }^{1}$ Accumulation of forage produced throughout the 1996-1997 growing season ( $\left.\mathrm{T}_{1} 270\right)$, and after cuttings carried out in midJanuary $\left(T_{1} 175\right)$ and mid-February $\left(T_{1} 145\right)$, and after cuttings carried out in mid-December $\left(T_{2} 215\right)$ and at the beginning of January $\left(\mathrm{T}_{2} 195\right)$ and February $\left(\mathrm{T}_{2} 165\right)$ during the 1997-1998 season.

${ }^{2}$ Means with different letters in each row differ among themselves according to the Tukey test $(\mathrm{P}<0.05)$.

${ }^{3}$ Means with different letters in the column differ among themselves according to the Tukey tests $(\mathrm{P}<0.05)$.

was not significant $(P=0.669)$ and in general, the OMI mean values by each techniques were different $(\mathrm{P}<0.05$; Table 3$)$, suggesting that the techniques used produced very different absolute results, although similar in relative terms.

The major difference found among the techniques for estimating OMI was de 19,1 and 24,6 $\mathrm{g} \mathrm{kg}^{-1} \mathrm{LW}^{0,75}$ day $^{-1}$ for the 1996-1997 and 1997-1998 growing seasons, respectively, while the differences owing to treatments were 5.3 and $10.1 \mathrm{~g} \mathrm{~kg}^{-1} \mathrm{LW}^{0,75}$ day $^{-1}$ for both seasons. In the present work, all the OMI estimates were above the value of $36.9 \mathrm{~g} \mathrm{~kg}^{-1} \mathrm{LW}^{0,75} \mathrm{day}^{-1}$, which was worked out by a stall-feeding trial with the same resources and under the same conditions of forage accumulation produced throughout the growing season (Ferri et al., 1998).

The variation in OMI due to the duration of the forage accumulation period can be determined by the effect of non-nutritional characteristics of the pasture (biomass quantity and structure) (Sollenberger and Burns, 2001), and by modification of the plant tissue structure and nutrient concentration. In the present work variations in fiber concentration and digestibility of forage between 
treatments were small. It is probable that modifications of the morphological development of the pasture, as a result of different accumulation periods, have had a greater relative effect on forage intake than modifications at the level of chemical components. The leaf:stem ratio could affect the dimensions of the bite and the biting rate (Drescher et al., 2006), and consequently, forage intake.

\section{Direct method or by cutting}

The experimental conditions to estimate intake by cutting were optimal to achieve precise measurements: short pasture cutting period, matched pre- and postgrazing sampling sites, pastures with a homogeneous botanic composition, and free of feces, forage removed representing an important proportion of the forage on offer (Macoon et al., 2003). Forage growing between cuttings determines the under-estimation of intake, with an important effect in periods of prolonged grazing $(>3 \mathrm{~d})$. Nevertheless, this effect is minimized with short grazing periods and high differences between the quantity of forage measured in pre- and post-grazing (Meijs et al., 1982) as in the present work. Given this, the accumulation of forage during the grazing period was not considered (the time between the pre- and post-grazing cuttings was 1 day, the difference in the quantity of forage between pre- and post-grazing was on average $1050 \mathrm{~kg} \mathrm{OM} \mathrm{ha}^{-1}$ ). To this can be added that the growth of deferred $P$. coloratum is close to nil during the winter period. On the other hand, this technique can overestimate intake owing to the reduction of forage by senescent leaves falling of and their subsequent carrying over by wind action or burial by trampling.

The disadvantages of the cutting technique are associated with the impossibility of obtaining estimations of individual intake, and the requirement of frequent sampling of the pasture. However, it has the advantage of getting forage intake data rapidly after the postgrazing cutting and estimation of forage DM and ash concentrations are performed.

\section{Total collection of feces and OMD estimated by the in vitro technique}

The exactitude of the estimation of intake using this method is more limited by measurement errors in digestibility by fecal excretions, which are bigger with increases in digestibility (Mayes and Dove, 2000). In the present work, forage digestibility in vitro values were low ( $\leq 401 \mathrm{~g} \mathrm{~kg}^{-1} \mathrm{OM}$; Table 2$)$, and therefore, the effect of errors in the measurement of digestibility on intake estimations will be reduced.
The in vitro technique is one of the most used to estimate diet digestibility, although it has several disadvantages (Mayes and Dove, 2000). It is difficult to obtain samples that represent the digestibility of the forage consumed by the animal at grazing, if animals with esophageal fistula are not used. On the other hand, the indirect estimation of digestibility of grazed forage involves determinations of forage mass and IVOMD in preand post-grazing. Consequently, the error associated with the estimation of diet digestibility is the result of the accumulated errors in the estimation of the four components of the equation (forage mass and IVOMD for both, pre- and post-grazing). Even if the samples are representative of the diet, in vitro digestibility, adjusted through in vivo measurements, could be different from the digestibility in vivo of the grazing animal. Forage in vivo digestibility at grazing could differ from the in vitro estimations owing to differences in the level of dietary intake or to the retention time in the rumen (Dove et al., 2000) of the grazing animals, in comparison with the animals used in the estimation of in vivo digestibility that a posteriori will be used (as a control value for in vitro digestibility determinations) to establish the in vitro:in vivo calibration.

\section{Total collection of feces and OMD estimated by the fecal $\mathbf{N}$ index}

The main problem presented by the fecal $\mathrm{N}$ index technique is the loss of $\mathrm{N}$ from fecal samples, which increases with higher concentrations of N. In the present work, fecal concentrations of $\mathrm{N}$ were low and varied between 10.2 and $14.5 \mathrm{~g} \mathrm{~kg}^{-1} \mathrm{OM}$, reason by which it was expected that $\mathrm{N}$ loss, due to drying of the feces, would remain at low and similar levels between treatments. On the other hand, the forage of all the treatments can be considered of low quality, taking into account the low cell content (1000 - FDN) and the values for other nutritional variables (Table 2) of the deferred forage evaluated. Total fecal N (TFN) per unit of OMI was not expected to be modified by the treatments, since a high and similar proportion of structural carbohydrates would be fermented in the rumen. In this way, the existing mathematical relation between digestibility values and the concentration of fecal $\mathrm{N}$ determined in conditions of confinement (Ferri et al., 2003) would also be seen for grazing conditions. Lukas et al. (2005) found little effect of diet composition variation on the concentration of fecal $\mathrm{N}$, and obtained a close relationship between OMD of and the concentration of fecal $\mathrm{N}$. The main advantages of this technique are its reduced and simple analytical work and no need for diet sampling. 


\section{$N$-alkanes}

One of the assumptions of the $n$-alkanes technique to estimate intake is the similar recovery of the $n$-alkanes pair (Dove and Mayes, 2005). Consequently, part of the variation among the estimations of intake using different pairs of $n$-alkanes could be associated with differences in fecal recovery between $n$-alkane pairs. Nevertheless, in the present work the differences among the estimations of OMI based on $n-\mathrm{C}_{31}: n-\mathrm{C}_{32}$ o $n-\mathrm{C}_{33}: n-\mathrm{C}_{32}$ pairs were inconsistent between growth seasons (Table 3).

In comparison to the other techniques evaluated, the $n$-alkanes technique overestimated grazing intake of rams (Table 3). These results could be explained by the possible lack of correspondence between the samples taken by pasture cutting and the animals' diets. Sheep have a strong preference for leaf blades (Ferri, 2002), which have a greater concentration of $n$-alkanes than the stems (Dove and Mayes, 2005). Consequently, the diet of the animal will have a greater concentration of $n$-alkanes than the samples obtained from the pasture. To ensure that the forage sampling reflects what is consumed from the standing biomass, several authors have suggested to use animals with esophageal fistula (Coates and Penning, 2000; Dove et al. 2000). Nevertheless, the esophageal samples (collected over periods of 10 to $30 \mathrm{~min}$ ) poorly reflect the daily variation in diet composition (Dove and Mayes, 2005), especially in rotating grazing with a rapid removal of forage. This suggests the need to study the pattern of $n$-alkanes for all the different morphological fractions, to evaluate the possibility of estimating the proportion of these fractions in the diet by fecal sampling (Mayes and Dove, 2000) and estimate the concentration of $n$ - alkanes in the ingested forage. Another possible explanation for the over-estimation in OMI would be the erroneous estimation of marker dose $\left(n-C_{32}\right)$. It is probable that some animals could regurgitate and expel the pellet containing the marker, as a result of which the calculations would be made with a marker dose value greater than the real one. A lower amount of marker effectively dosed would mean a lower concentration in feces, thus giving way to an over-estimation in the quantity of both feces excretion and forage intake. Nevertheless, in this work regurgitated pellets were not observed in the pasturing area.

In relation to the remaining techniques for indirect estimation of intake, the $n$-alkanes technique is characterized by not using estimations of daily excretion of feces and diet digestibility. However, it requires costly equipment to analyze the material.

\section{Comparisons of intake estimation techniques}

The most closely correlated estimations of OMI were those obtained using the total collection of feces combined with OMD, the latter being determined by the in vitro technique or the fecal $\mathrm{N}$ index (Table 4). These are followed by the estimations made using the $n$-alkane pairs, $n$-alkanes $n$ - $\mathrm{C}_{31}: n-\mathrm{C}_{32}$ and $n-\mathrm{C}_{33}: n-\mathrm{C}_{32}$. The estimations based on the $n$-alkane procedure were more closely associated to those obtained by technique including $\mathrm{OMD}_{\mathrm{N} \text { fecal }}$ measurements than those produced by the approach comprising $\mathrm{OMD}_{\text {in vitro }}$ determinations. A probable explanation of the latter is that fecal N, like $n$-alkanes, allows for obtaining an estimation of individual variation in OMD. The cutting technique tended $(\mathrm{P}<0.10)$ to be correlated to the total collection of feces and $\mathrm{OMD}_{\text {invitro, }}$, while the correlations with the

Table 4. Correlations between estimations of organic matter intake of rams grazing on Panicum coloratum cv. Verde obtained from the difference between pre- and post-grazing (pre$P$ - pos-P) from the total daily feces collection in combination with organic matter diet digestibility, assessed by the in vitro technique $\left(\mathrm{OMD}_{\text {in vitro }}\right)$ or the fecal $\mathrm{N}$ index $\left(O M D_{\mathrm{N} \text { fecal }}\right)$, and the $n$-alkane technique using $n-C_{31}: n-C_{32}$ or $n-C_{33}: n-C_{32}$ pairs $(n=12)$.

\begin{tabular}{|c|c|c|c|c|}
\hline & \multirow{2}{*}{$\begin{array}{c}\text { Forage } \\
\text { Pre-P - pos-P }\end{array}$} & \multicolumn{2}{|c|}{ Total collection of feces } & \multirow{2}{*}{$\begin{array}{l}N \text {-alkanes } \\
n-C_{31}: n-C_{32}\end{array}$} \\
\hline & & $\mathbf{O M D}_{\text {in vitro }}$ & $\mathbf{O M D}_{\mathrm{N} \text { fecal }}$ & \\
\hline \multicolumn{5}{|c|}{ Total collection of feces } \\
\hline $\mathrm{OMD}_{\text {in vitro }}$ & $0.52 \S$ & - & & \\
\hline $\mathrm{OMD}_{\mathrm{N} \text { fecal }}$ & $0.45^{\circ}$ & $0.83^{* * *}$ & - & \\
\hline \multicolumn{5}{|l|}{$N$-alkanes } \\
\hline$n-\mathrm{C}_{31}: n-\mathrm{C}_{32}$ & 0.23 & $0.51 \S$ & $0.63^{*}$ & - \\
\hline$n-\mathrm{C}_{33}: n-\mathrm{C}_{32}$ & 0.16 & 0.40 & $0.63^{*}$ & $0.64 *$ \\
\hline
\end{tabular}

${ }^{\S} \mathrm{P}<0.10 ; * \mathrm{P}<0.05 ;{ }^{* * *} \mathrm{P}<0.001$. 
remaining techniques evaluated were not significant $(r \leq 0.45 ; \mathrm{P}>0.05)$.

There is scarce information about comparisons between the cutting and n-alkane techniques. Smit $e t$ al. (2005) found significant but weak correlations $(r<$ 0.50 ) between these techniques, while the correlations observed by the same authors between intake estimations using different $n$-alkane pairs were close $(r>0.90)$. On the other hand, there is abundant evidence on the inconsistency of the relationship between techniques that employ in vitro digestibility to predict the digestibility of the diet and the $n$-alkanes technique (Dove et al., 2000; Mayes and Dove, 2000).

\section{CONCLUSIONS}

The study shows the difficulties associated with obtaining accurate estimations of intake under grazing conditions. In general terms, the techniques used were sensitive to the effect of treatments (periods of forage accumulation) and one of the main problems encountered was the collection of samples that were representative of the animals' diets. Consequently, the technique choice will depend on the possibility of obtaining samples representative of the diet, type of evaluation required (group or individual) and the available analytical facilities.

The herbage cutting technique requires a significant level of field work in taking samples. Nevertheless, this sampling can be required to characterize the pasture and explain the animal response. The indirect estimates of intake most closely associated among themselves were those obtained based on the total collection of feces combined with the digestibility of consumed forage, the latter being determined using the in vitro technique or the fecal $\mathrm{N}$ index. The in vitro technique, unlike the fecal $\mathrm{N}$ index, ignores animal variation in digestibility. Besides, in order to use the in vitro technique it is necessary to have an ovine or bovine with rumen fistula as a source of innoculum. The technique of fecal $\mathrm{N}$ index requires feeding tests to estimate total fecal nitrogen, using the same forage as in the grazing condition. The utility of this technique is thus restricted to situations where the forage used at grazing can be harvested and employed simultaneously to carry out stall-feeding tests. Apparently the $n$-alkanes method over-estimates OMI, which could be due to errors introduced in diet sampling. The application of this technique requires further studies to be able to predict $n$-alkanes concentrations in consumed forage.
R E S U M E N

Comparación de cuatro técnicas para la estimación del consumo de forraje por ovinos en una pastura de Panicum coloratum L. Carlos M. Ferri ${ }^{1 *}$, Néstor P. Stritzler ${ }^{2}$, Miguel A. Brizuela ${ }^{3}$, y Horacio J. Pagella1 $^{1}$ La estimación del consumo diario de alimentos es importante en la producción animal. El objetivo del experimento fue comparar el consumo animal estimado mediante cuatro técnicas: diferencia entre la biomasa de forraje medida por corte en pre- $y$ pospastoreo, recolección total de heces combinada con digestibilidad in vitro de la dieta, recolección total de heces combinada con digestibilidad de la dieta estimada a partir del índice del $\mathrm{N}$ fecal, y método de los $n$-alcanos. La comparación se realizó en una pastura de Panicum coloratum L. diferida. En la primera estación de crecimiento los tratamientos se establecieron por acumulación del forraje producido, luego de un corte mecánico realizado a $8 \mathrm{~cm}$ de altura a mediados de octubre, de enero y de febrero. En la segunda estación, los tratamientos se generaron por la acumulación del forraje producido después de un corte realizado a mediados de diciembre, y principios de enero y febrero. Los tratamientos se asignaron al azar en parcelas de 0,5 ha con dos repeticiones. Las estimaciones del consumo correlacionadas más estrechamente entre sí $(r=0,83$; $\mathrm{P}<0,01)$ fueron las obtenidas a través de la producción total de heces combinada con la digestibilidad de la dieta determinada mediante la técnica in vitro o por el índice del $\mathrm{N}$ fecal. Aparentemente, la técnica de los $n$-alcanos sobreestimó el consumo de forraje, lo cual podría deberse a errores en el muestreo de la dieta. En términos generales, las técnicas empleadas para estimar el consumo fueron sensibles a los efectos del tratamiento.

Palabras clave: consumo de forraje, gramínea $\mathrm{C}_{4}$, $n$-alcanos, nitrógeno fecal. 


\section{LITERATURE CITED}

Alexander, R.H., and M. McGowan. 1966. The routine determination of in vitro digestibility of organic matter in forages. An investigation of the problems associated with continuous large scale operation. J. Br. Grassl. Soc. 21:140-147.

Coates, D.B., and P. Penning. 2000. Measuring animal performance. p. 353-402. In t'Mannetje L., and R.M. Jones (eds.) Field and laboratory methods for grassland and animal production research. CAB International, Wallingford, UK.

Dove, H., M. Freer, and J.Z. Foot. 2000. The nutrition of grazing ewes during pregnancy and lactation: a comparison of alkane-based and chromium/in vitrobased estimates of herbage intake. Aust. J. Agric. Res. 51:765-777.

Dove, H. and R.W. Mayes. 2005. Using $n$-alkanes and other plant was components to estimate intake, digestibility and diets composition of grazing/browsing sheep and goats. Small Rum. Res. 59:123-139.

Drescher, M., I.M.A. Heikoning, J.G. Raats, and H.H.T. Prins. 2006. The role of grass items as structural foraging deterrents and their effects on the foraging behaviour of cattle. Appl. Anim. Behav. Sci. 101:10-26.

Ferri, C.M. 2002. Implicancias del diferimiento de la utilización de Panicum coloratum L. sobre la estructura de la vegetación, la composición química del forraje y el consumo de ovinos en pastoreo. $161 \mathrm{p}$. Tesis de Doctorado en Ciencias Agrarias. Universidad Nacional de Mar del Plata, Balcarce, Argentina.

Ferri, C.M., J.H. Pagella, M.A. Brizuela, y N.P. Stritzler. 2007. Concentración de $n$-alkanes en Panicum coloratum cv. Verde. p. 277-279. In V Congreso Latinoamericano de Especialistas en Pequeños Rumiantes y Camélidos Sudamericanos, Mendoza, Argentina. 02-05 de mayo de 2007. Asociación Latinoamericana de Especialistas en Pequeños Rumiantes y Camélidos Sudamericanos, Mendoza, Argentina.

Ferri, C.M., H.J. Petruzzi, N.P. Stritzler, y V.V. Jouve. 1998. Consumo voluntario, digestibilidad in vivo y proteína bruta dietaria en distintas épocas de utilización de Panicum coloratum diferido. Rev. Arg. Prod. Anim. 8:163-170.

Ferri, C.M., N.P. Stritzler, M.A. Brizuela, and H.J. Petruzzi. 2003. In vivo digestibility of kleingrass from fecal nitrogen excretion. J. Range Manage. 56:52-55.

Ferri, C.M., N.P. Stritzler, M.A. Brizuela, F.I. Piper, y H.J. Petruzzi. 2001. Efecto de la oferta de pasto sobre la ingestión de ovinos en pastoreo de Panicum coloratum L. diferido. Invest. Agrar. Prod. Sanid. Anim. 16:281-289.
Lippke, H. 2002. Estimation of forage intake by ruminants on pasture. Crop Sci. 42:869-872.

Lukas, M., K.-H. Südekum, G. Rave, K. Friedel, and A. Susenbeth. 2005. Relationship between fecal crude protein concentration and diet organic matter digestibility in cattle. J. Anim. Sci. 83:1332-1344.

Macoon, B., L.E Sollenberger, J.E. Moore, C.R. Staples, J.H. Fike, and K.M. Portier. 2003. Comparison of three techniques for estimating the forage intake of lactating dairy cows on pasture. J. Anim. Sci. (Cambridge) 81:2357-2366.

Mayes, R.W., and H. Dove. 2000. Measurement of dietary intake in free-ranging mammalian herbivores. Nutr. Res. Rev. 13:107-138.

Mayes, R.W., H. Dove, X.B. Chen, and J.A. Guada. 1995. Advances in the use of faecal and urinary markers for measuring diet composition, herbage intake and nutrition utilization in herbivores. p. 341-406. In Journet, M. et al. (eds.) Recent developments in the nutrition of herbivores. INRA Editions, Paris, France.

Mayes, R.W., C.S. Lambs, and P.M. Colgrove. 1986. The use of dosed and herbage $n$-alkanes as markers for the determination of herbage intake. J. Agric. Sci. (Cambridge) 107:161-170.

Meijs, J.A.C., R.J.K. Walters, and A. Keen. 1982. Swards methods. p. 11-36. In J.D. Leaver (ed.) Herbage intake handbook. The British Grassland Society, Hurley, UK.

Rymer, C. 2000. The measurement of forage digestibility in vivo. p. 113-134. In Givens, D.I. et al. (eds.) Forage evaluation in ruminants. CAB International, Wallingford, Oxon, UK.

Smit, H.J., H.Z. Taweel, B.M. Tas, S. Tamminga, and A. Elgersma. 2005. Comparison of techniques for estimating herbage intake of grazing dairy cows. J. Dairy Sci. 88:1827-1836.

Sollenberger, L.E., and J.C. Burns. 2001. Canopy characteristics, ingestive behaviour and herbage intake in cultivated tropical grassland. p. 321-327. Proc. XIX Int. Grassl. Congr., Sao Pedro, Sao Paulo, Brazil. 11-21 February 2001. Brazilian Society of Animal Husbandry, Piracaciba, Sao Paulo, Brazil.

Van Soest, P.J., and J.B. Robertson. 1985. Analysis of forage and fibrous food. 165 p. Cornell Univ. Press, Ithaca, New York, USA. 